\title{
Ecological, anatomical and physiological traits of benthic macroinvertebrates: Their use on the health characterization of freshwater ecosystems
}

\section{T. Jesus}

CEMAS, Faculdade de Ciência e Tecnologia da Universidade Fernando Pessoa, Praça 9 de Abril, 4249-004 Porto, Portugal, E-mail: tjesus@ufp.pt or tmjesus@ sapo.pt

* Corresponding author:

Received: 22/4/07

Accepted: 11/10/07

\begin{abstract}
Ecological, anatomical, and physiological traits of benthic macroinvertebrates: their use on the health characterization of freshwater ecosystems

After some studies made in Northern Portuguese freshwater ecosystems using the benthic macroinvertebrate communities for water quality evaluation, it has been possible to see that only the analysis of some characteristics allowed to distinguish different levels of environmental disturbance.

The studies of some characteristics of the macroinvertebrates and the comparison with the results of the physico-chemical parameters analysed show that the more disturbed the ecosystems had, the lower dissolved oxygen concentration and organisms with greater independence from this concentration.

The objective of this work is to define groups of organisms, attending to some of their characteristics that are related to getting oxygen.

The groups were defined through bibliographic information and from direct observation of their behaviour. The ability of these groups to distinguish different types of ecosystems was analysed by comparison of the obtained results on their distribution in a group of sampling sites located along gradients of contamination, with the results obtained by the calculation of biological indices, descriptive metric analyses of the community, and the water chemical quality.

After this study, it is possible to say that the results obtained with the use of respiratory groups can be more informative than that obtained with the analysis of the physico-chemical parameters or other biological parameters.
\end{abstract}

Key words: Macroinvertebrates, breathing physiology, water quality, limnology.

\section{RESUMEN}

Características ecológicas, anatómicas y fisiológicas de macroinvertebrados bentónicos: Su uso en la caracterización de la salud de ecosistemas de aguas dulces

Tras diversos estudios efectuados en ecosistemas acuáticos del Norte de Portugal usando las comunidades de macroinvertebrados para evaluar la calidad del agua ha sido posible verificar que solo el estudio de algunas características permitía diferenciar niveles de perturbación ambiental.

El estudio de algunas características de los macroinvertebrados y la comparación con los resultados de los parámetros físico-químicos analizados ha mostrado que cuanto más perturbados eran los sistemas, menor era la concentración de oxigeno disuelto y más independientes de su concentración los organismos presentes.

El objetivo de este trabajo es definir grupos de organismos, atendiendo a algunas de sus características relacionadas con la obtención de oxigeno.

Los grupos fueran definidos a través de información de bibliografía y de la observación directa de su comportamiento. La capacidad de los grupos para distinguir los diferentes tipos de ecosistemas fue analizada través la comparación de los resultados obtenidos de su distribución en un conjunto de puntos de muestreo ubicados a lo largo de gradientes de contaminación con resultados obtenidos por el cálculo de índices biológicos, análisis métricos descriptivos de la comunidad y de la calidad química del agua.

Al final de este estudio es posible decir que los resultados obtenidos con los grupos respiratorios pueden ser más informativos que los obtenidos con el análisis de los parámetros físico y químicos o con otros parámetros biológicos.

Palabras clave: Macroinvertebrados, fisiología respiratoria, calidad del agua, limnología. 


\section{INTRODUCTION}

In many studies, the values of biotic indices and the study of benthic macroinvertebrate communities through the interpretation of the diversity, richness, and equitability indices produce results that are not compatible with the values obtained with the study of other type of parameters (Usseglio-Polatera, 1994; Jesus, 1996; Jesus, 2001).

In order to solve these problems it is possible to perform studies on the communities' taxonomic composition by different statistical methods, calculation of some metrics, and comparison of results obtained with the benthic macroinvertebrates communities with results obtained by through analysis of some physico-chemical parameters.

After analysis of the results from several studies, it was possible to conclude that the physiological tolerance limits of different stream organisms influence their ability to be in a specific situation or habitatand that there is a strong relation between the dissolved oxygen concentration in the water and the taxa present in each ecosystem type (Ross et al., 1982; Resh \& Rosenberg, 1984; Mouthon, 1992; Williams \& Feltmate, 1992; Statzner et al., 1994; Usseglio-Polatera, 1994).

Therefore, the main objectives of the present study are to propose a classification system of benthic macroinvertebrates based on their anatomical and physiological respiratory characteristics and to test the use of the defined respiratory groups in the evaluation of the water quality in different Portuguese freshwater ecosystems.

\section{MATERIAL AND METHODS}

\section{Definition of the respiratory groups}

The definition of the respiratory groups was done using information obtained from specific bibliography and from observation of the organisms in their own habitat (Hynes, 1979; Mouthon, 1982; Ross et al., 1982; Lafont, 1983; Resh \& Rosenberg, 1984; Faessel, 1985; Chinery, 1992; Williams \& Feltmate, 1992; Wetzel, 1993; Campaioli et al., 1994, 1999; Fitter \& Manuel, 1994; Forey \& Forey, 1995; Reichfold-
Riehm, 1995; Forey \& Fitzisimons, 1996; Giller \& Malmqvist, 1998; Puig, 1999).

\section{Testing the use of respiratory groups}

The testing of the use of the defined respiratory groups into de determination of the biological water quality was performed using two case studies developed with data collected in some Northern Portuguese freshwater ecosystems (Table 1).

Sampling site characterization was made through the determination of some physicochemical parameters (air and water temperature, alkalinity, hardness, $\mathrm{pH}$, conductivity, dissolved oxygen concentration, biochemical oxygen demand $\left(\mathrm{BOD}_{5}\right)$, nitrates, nitrites, ammonium, and phosphates concentration) according to the techniques described in APHA (1992), Strickland \& Parsons (1972) and Welch (1948).

Macroinvertebrate communities were sampled at each sampling site with a hand net (Jesus, 2002) in order to determine the number of organisms and taxa, Shannon-Weaver diversity index, Pielou equitability index and two biotic indices were calculated (Belgium Biotic Index from De Pauw \& Vanhooren (1983) and the Iberian Monitoring Party Score Systems from Alba-Tercedor \& Sanchéz-Ortega (1988)).

In the first case study, data collected in all sampling sites in the Spring (one sample per site) was used. The second case study was performed with data collected only in the four lagoons of the Wastewater Treatment Plant of Albergaria-a-Velha (Table 1) throughout one year (since May 95 to April 96).

The first case study, was done with data of the physico-chemical parameters, and a spatial ordination of the samples by a Principal Component Analysis. With the data from the macroinvertebrate communities, an analysis of spatial variation of the biotic parameters and indices was performed (Jesus, 2001). With the macroinvertebrates' data grouped into the defined respiratory groups, a n-MDS analysis was carried out followed by the validation and determination of the main groups responsible for the differentiation between the sampling sites using the ANOSIM and K-means per- 
Table 1. General characterization of analyzed ecosystems. Caracterización general de los ecosistemas analizados.

\begin{tabular}{|c|c|c|}
\hline Ecosystem & General characterization & Sampling sites \\
\hline \multirow[t]{3}{*}{ Albergaria Stream } & \multirow{3}{*}{$\begin{array}{l}\text { Water course of the Vouga basin that receive the effluent } \\
\text { of the wastewater treatment power plant of } \\
\text { Albergaria-a-Velha }\end{array}$} & Alb1 - upstream the effluent \\
\hline & & Alb2 - downstream the effluent \\
\hline & & $\begin{array}{l}\text { Alb3 - some kilometres downstream the } \\
\text { effluent }\end{array}$ \\
\hline \multirow[t]{3}{*}{ Âncora river } & \multirow{3}{*}{$\begin{array}{l}\text { Small river, with about } 18 \text { kilometers on the North of } \\
\text { Portugal with several cascades }\end{array}$} & Anc1 - on the crenon area \\
\hline & & Anc2 - on the ritron area \\
\hline & & Anc3 - on the potamon area \\
\hline \multirow{4}{*}{$\begin{array}{l}\text { Wastewater treatment } \\
\text { power plant of } \\
\text { Albergaria-a-Velha }\end{array}$} & \multirow{4}{*}{$\begin{array}{l}\text { A biological wastewater treatment plant that use a } \\
\text { treatment type constituted by } 4 \text { lagoons }\end{array}$} & WTP1 - aerated lagoon \\
\hline & & WTP2 - 1st sedimentation lagoon \\
\hline & & WTP3 - 2nd sedimentation lagoon \\
\hline & & WTP4 - maturation lagoon \\
\hline \multirow[t]{3}{*}{ Alva river } & \multirow{3}{*}{$\begin{array}{l}19 \text { first kilometres of the river with a flood regime very } \\
\text { altered by the functioning of a cascade of } 4 \text { small } \\
\text { hydroelectric power plants }\end{array}$} & Alv1 - reference point \\
\hline & & Alv2 - between the dam and the discharge \\
\hline & & Alv3 - downstream the discharge \\
\hline Caniça stream & Little tributary of Alva river & Can \\
\hline \multirow[t]{3}{*}{ Ardena river } & \multirow{3}{*}{$\begin{array}{l}\text { Small river, tributary of Paiva river (Douro basin) with } \\
\text { many little dams and with one small hydroelectric power } \\
\text { plant }\end{array}$} & Ard1 - reference point \\
\hline & & $\begin{array}{l}\text { Ard2 - between the dam and the } \\
\text { discharge }\end{array}$ \\
\hline & & Ard3 - downstream the discharge \\
\hline Azibo river & $\begin{array}{l}\text { A tributary of Sabor river with a big dam upstream the } \\
\text { sampling site }\end{array}$ & Azi \\
\hline \multirow[t]{3}{*}{ Sabor river } & \multirow{3}{*}{ Water course of the Douro hydrographical basin } & Sab1 - on the ritron area \\
\hline & & Sab2 - on the potamon area \\
\hline & & $\begin{array}{l}\text { Sab3 - on the potamon area, near the } \\
\text { mouth }\end{array}$ \\
\hline Vilariça stream & Little stream tributary of Sabor river & Vil \\
\hline Febros river & $\begin{array}{l}\text { Small river affluent of Douro river with a moderate } \\
\text { degree of organic pollution }\end{array}$ & Feb \\
\hline
\end{tabular}

formed by PRIMER 5.2.2 and STATISTICA 6.1 software (Clarcke \& Green, 1988; Clarcke, 1993; Clarcke et al., 1993; Clarcke \& Warwick, 1994; Field et al., 1982; STATSOFT, 1998).

\section{RESULTS}

\section{Definition of the respiratory groups}

The analysis of specific bibliography and the observation of the macroinvertebrate behaviour in different types of ecosystems allowed the definition of seven respiratory groups:
1) Aerial respiration includes organisms that live on the water surface where they can access the atmospheric oxygen and store it in a bubble beneath the elytra or over the ventral surface (this bubble function as a gill or lung). It also includes organisms that live submerged all the time and breathe through a tube or pair of tubes that can break through the water surface (only the pair of spiracles connected with these tubes are functional). These organisms are completely independent of the dissolved oxygen in the water, so they can be found in very polluted ecosystems. Examples: Heteroptera, Hymnoptera, Coleoptera (except the larvae of 
a)

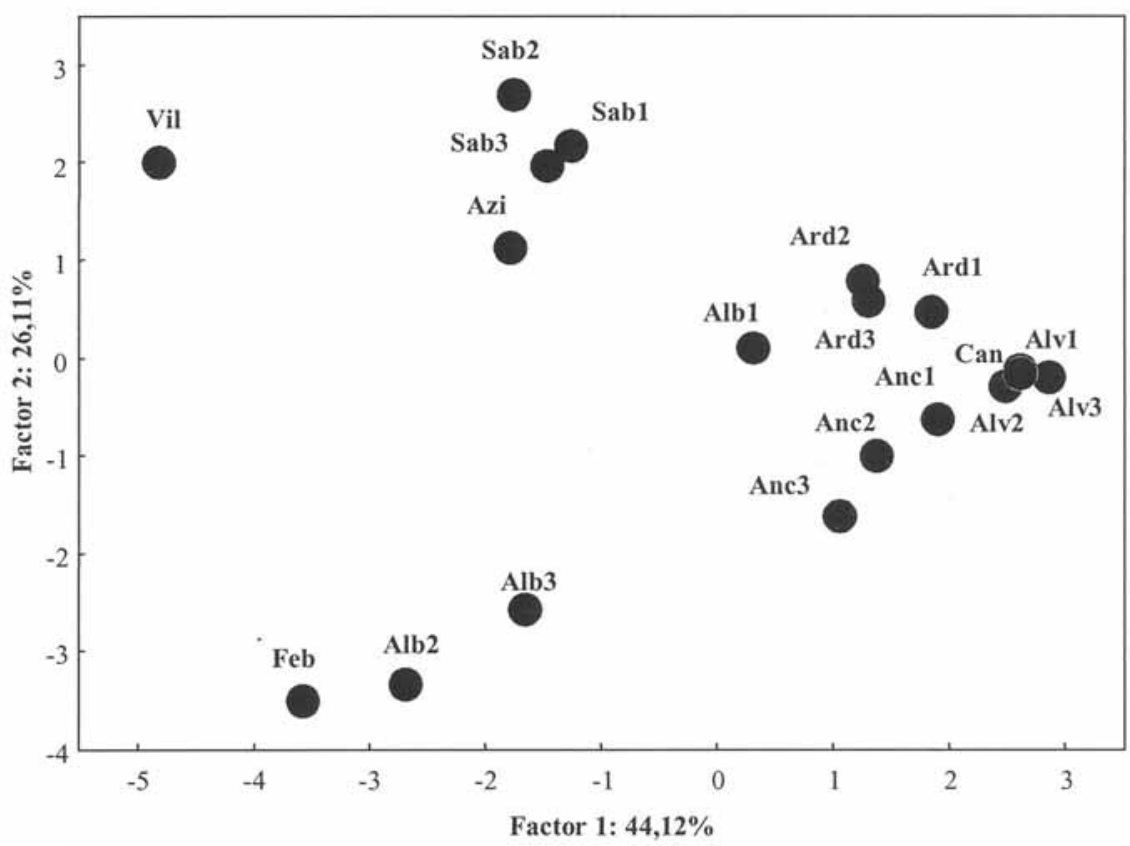

b)

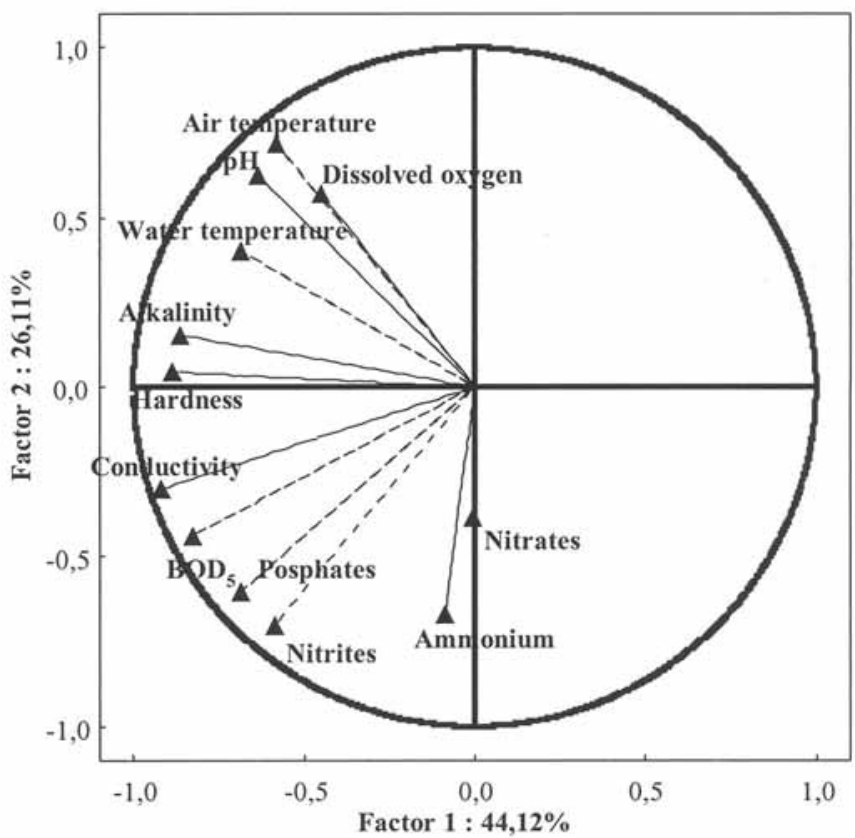

Figure 1. Sample ordination for the main physic-chemical parameters analysis in all sampling sites in the space formed by the two first factors of the principal components analysis (PCA) (explained variance: factor 1-44.12\%; factor 2-26.11\%) (a) and the representation of the correlation circle of the physico-chemical parameters determined by the two PCA first axis .(b). Ordenación de las muestras en todas las estaciones de muestreo según el análisis de los principales parámetros físico-químicos, en el espacio formado por los dos primeros factores del Análisis de Componentes Principales (PCA) (varianza explicada: factor 1-44.12\%; factor $2-26.11 \%(a)$ y representación del círculo de correlación de los parámetros físico-químicos determinado con los dos primeros ejes del PCA $(b)$ 
Elmidae, Gyrinidae, Hygrobiidae, Psephenidae) and some Diptera (Anthomyidae, Psychodidae, Ptychopteridae, Tabanidae, Chaoboridae, Syrphidae, Stratiomyidae, Dixidae, Culicidae).

2) Branchial respiration include larvae of insects that live submerged all the time and that have an obliteration of all spiracles and a development of external tracheal gills (lateral, ventral, dorsal, or caudal) that are very important in oxygen uptake, as well as organisms that have true internal gills. They are common in running waters or well-aerated lentic waters, where their distribution may be closely linked to available oxygen. Examples: Bivalvia, Gasteropoda, Crustacea, Ephemeroptera, Odonata zigoptera, some Plecoptera (Amphinemura, Protonemura, Perlidae) Megaloptera, Lepidoptera, the Coleoptera larvae of Hygrobiidae elmidae, Gyrinidae, Eubriidae, Trichoptera (except Erotesis, Mystacides, Triaenodes, Beraeidae, Sericostomatidae, Ecnomidae, Helicopsychidae, Psychomyiidae, Molannidae, Glossosomatidae), and some Diptera (Tipuliidae, Limoniidae, Empididae, Blephariceridae, Athericidae).

3) Cutaneous respiration is typical of organisms that live submerged all the time and that have no tracheal system. The gas exchange within the body is achieved by diffusion through the tissues. This type of respiration may suffice only for the smallest aquatic insects or organisms with a flattened body because their cuticle is extremely impermeable. Insects that have a tracheal system, have the spiracles replaced by a cluster of fine sub-epidermical tracheas and the gas exchange takes place first through the epidermis and then into the fine peripheral tracheae. This kind of respiration tends to be common in organisms that live in running waters or well-aerated lentic waters, where their distribution may be closely linked to available oxygen. Examples: Turbellaria, Nematoda, Hirudinea, Plecoptera (except Protonemura, Amphinemura and Perlidae) Trichoptera (Helicopsychidae, Beraeidae, Ecnomidae, Molannidae, Mystacides, Erotes, Triaenode, Glossosomatidae, Psychomyiidae, Sericostomatidae), and Diptera: (Ceratopogonidae, Sciomyzidae, Dolichopodidae).
4) Pulmonary respiration includes organisms that have a richly vascularized paleal cavity in the mantle, without gills, that function as a "lung". They are relatively independent of the water's oxygen because they breathe air directly and live near of the water surface or associated to macrophyte leaves very close to the surface Examples: Gasteropoda pulmonata.

5) Branchial and aerial respiration is typical of organisms that have reduced tracheal gills and that can obtain atmospheric oxygen at the water surface. These organisms are less sensitive to organic pollution because they can survive with the atmospheric oxygen. Examples: Odonata Anisoptera and the Diptera Ephydridae.

6) Branchial and cutaneous respiration includes organisms that have cutaneous respiration but need other mechanisms for a substantial oxygen uptake. They can have cuticular modifications surrounding the open spiracles, which function as gills that allow for an increase in their dissolved oxygen extraction rate without spiracular contact with the atmosphere, and the surface of the larvae are richly supplied with fine tracheae. Examples: Simuliidae and some Chironomidae.

7) Special cases include organisms that have branchial and/or cutaneous respiration but that also have respiratory pigments in the blood. They are organisms that have great resistance even on anoxic environments. Examples: Red Chironomidae and some Oligochaeta.

\section{Case study 1}

The ordination of sampling sites (except those obtained from the wastewater treatment plant), having in mind the values obtained with the physico-chemical parameters, show a separation between the three main types of sites (Fig. 1a) along the two first axis. The most polluted sites include the two points of Albergaria stream (Alb2, Alb3) downstream the discharge of the effluent and the sampling sites at Febros river. The non-polluted rivers include the Âncora, Ardena and Alva rivers, Caniça stream and the upstream point of Albergaria stream (Alb1). Finally, the Sabor river and their tributaries (Vilariça stream and Azibo river) are in an intermediate position with respect to pollution. 
Table 2. Spatial variation of some indexes and metrics related to the benthic macroinvertebrate communities present in each sampling site of the case study one (BBI-Biotic Belgium Index; IBMWP-Iberian Biological, Monitoring Working Party). Variación espacial de algunos índices y métricas relacionados con las comunidades bentónicas de macroinvertebrados presentes en cada punto muestreo del primer estudio (BBI-Índice Biótico Belga; IBMWP-Iberian Biological, Monitoring Working Party).

\begin{tabular}{|c|c|c|c|c|c|c|}
\hline $\begin{array}{l}\text { Sampling } \\
\text { Sites }\end{array}$ & $\begin{array}{l}\text { Number of } \\
\text { organisms }\end{array}$ & $\begin{array}{c}\text { number of } \\
\text { taxa }\end{array}$ & $\begin{array}{l}\text { IBMWP } \\
\text { classes }\end{array}$ & $\begin{array}{c}\text { IBB } \\
\text { classes }\end{array}$ & $\begin{array}{c}\text { Shannon-Weaver } \\
\text { diversity }\end{array}$ & $\begin{array}{c}\text { Pielou } \\
\text { equitability }\end{array}$ \\
\hline Alb1 & $\geq 1000$ and $<5000$ & $<10$ & III & III & $<1$ & $<0.25$ \\
\hline Alb2 & $\geq 5000$ & $\geq 10$ and $<20$ & III & II & $<1$ & $\geq 0.25$ and $<0.5$ \\
\hline Alb3 & $\geq 500$ and $<1000$ & $\geq 10$ and $<20$ & II & III & $\geq 1-2$ & $\geq 0.5$ and $<0.75$ \\
\hline Alv1 & $\geq 100$ and $<500$ & $\geq 30$ and $<40$ & $\mathrm{I}$ & $\mathrm{I}$ & $\geq 2$ & $\geq 0.5$ and $<0.75$ \\
\hline Alv2 & $\geq 500$ and $<1000$ & $\geq 30$ and $<40$ & I & $\mathrm{I}$ & $\geq 2$ & $\geq 0.5$ and $<0.75$ \\
\hline Alv3 & $<100$ & $<10$ & IV & III & $\geq 1$ and $<2$ & $\geq 0.5$ and $<0.75$ \\
\hline Anc1 & $\geq 500$ and $<1000$ & $\geq 40$ and $<50$ & $\mathrm{I}$ & $\mathrm{I}$ & $\geq 2$ & $\geq 0.75$ \\
\hline Anc2 & $\geq 100$ and $<500$ & $\geq 20$ and $<30$ & $\mathrm{I}$ & $\mathrm{I}$ & $\geq 2$ & $\geq 0.75$ \\
\hline Anc3 & $\geq 100$ and $<500$ & $\geq 20$ and $<30$ & I & I & $\geq 2$ & $\geq 0.75$ \\
\hline Ard1 & $\geq 500$ and $<1000$ & $\geq 30$ and $<40$ & I & I & $\geq 2$ & $\geq 0.5$ and $<0.75$ \\
\hline Ard2 & $\geq 100$ and $<500$ & $\geq 20$ and $<30$ & $\mathrm{I}$ & $\mathrm{I}$ & $\geq 2$ & $\geq 0.5$ and $<0.75$ \\
\hline Ard3 & $\geq 100$ and $<500$ & $\geq 30$ and $<40$ & $\mathrm{I}$ & $\mathrm{I}$ & $\geq 1$ and $<2$ & $\geq 0.25$ and $<0.5$ \\
\hline Azi & $\geq 100$ and $<500$ & $\geq 20$ and $<30$ & I & $\mathrm{I}$ & $\geq 2$ & $\geq 0.5$ and $<0.75$ \\
\hline Can & $\geq 500$ and $<1000$ & $\geq 30$ and $<40$ & $\mathrm{I}$ & $\mathrm{I}$ & $\geq 2$ & $\geq 0.75$ \\
\hline WTP1 & $\geq 100$ and $<500$ & $<10$ & IV & III & $<1$ & $\geq 0.25$ and $<0.5$ \\
\hline WTP2 & $\geq 1000$ and $<5000$ & $<10$ & $\mathrm{~V}$ & III & $<1$ & $\geq 0.25$ and $<0.5$ \\
\hline WTP3 & $\geq 100$ and $<500$ & $<10$ & IV & III & $\geq 1$ and $<2$ & $\geq 0.5$ and $<0.75$ \\
\hline WTP4 & $>5000$ & $\geq 10$ and $<20$ & IV & III & $<1$ & $\geq 0.25$ and $<0.5$ \\
\hline Feb & $\geq 1000$ and $<5000$ & $\geq 10$ and $<20$ & III & III & $<1$ & $\geq 0.25$ and $<0.5$ \\
\hline Sab1 & $\geq 100$ and $<500$ & $\geq 10$ and $<20$ & II & II & $\geq 1$ and $<2$ & $\geq 0.25$ and $<0.5$ \\
\hline Sab2 & $\geq 100$ and $<500$ & $<10$ & IV & III & $\geq 1$ and $<2$ & $\geq 0.5$ and $<0.75$ \\
\hline Sab3 & $\geq 100$ and $<500$ & $<10$ & IV & III & $\geq 1$ and $<2$ & $\geq 0.5$ and $<0.75$ \\
\hline Vil & $\geq 500$ and $<1000$ & $20-30$ & II & II & $>2$ & $\geq 0.5$ and $<0.75$ \\
\hline
\end{tabular}

The first $\mathrm{X}$-axis reflects the variations in $\mathrm{pH}$, dissolved oxygen, and nutrient concentration, while the Y-axis is determined by the alkalinity, hardness, and conductivity. Factors like the air and water temperature and $\mathrm{BOD}_{5}$ are correlated with both axes (Fig. 1b). Therefore, this separation is due mainly to factors such as dissolved oxygen concentration, conductivity, and nutrient concentration factors, closely related to the pollution degree (Peckarsky et al., 1990; Giller \& Malmqvist, 1998; Gasith \& Resh, 1999) and parameters such as the air and water temperature and parameters influenced by the geology of region (hardness, alkalinity, $\mathrm{pH}$ ).

The spatial variation of the $\mathrm{O}_{2}$ concentration and $\mathrm{BOD}_{5}$ show that all systems have no problems with water oxygenation except the sampling sites located at the wastewater treatment plant. It is possible to observe that there is an increase in the values of $\mathrm{BOD}_{5}$ in the Febros river, Albergaria stream and this fact can be an indicator of an increase of organic pollution (Fig. 2). It is important to note that all sampling sites, except the lagoons of the wastewater treatment plant, present some algae developments.

The analysis of the spatial variation of some biotic parameters and indices related to the macroinvertebrate communities show that there are great differences between the sampling sites, but it is possible to define 3 groups of samples (Table 2): 


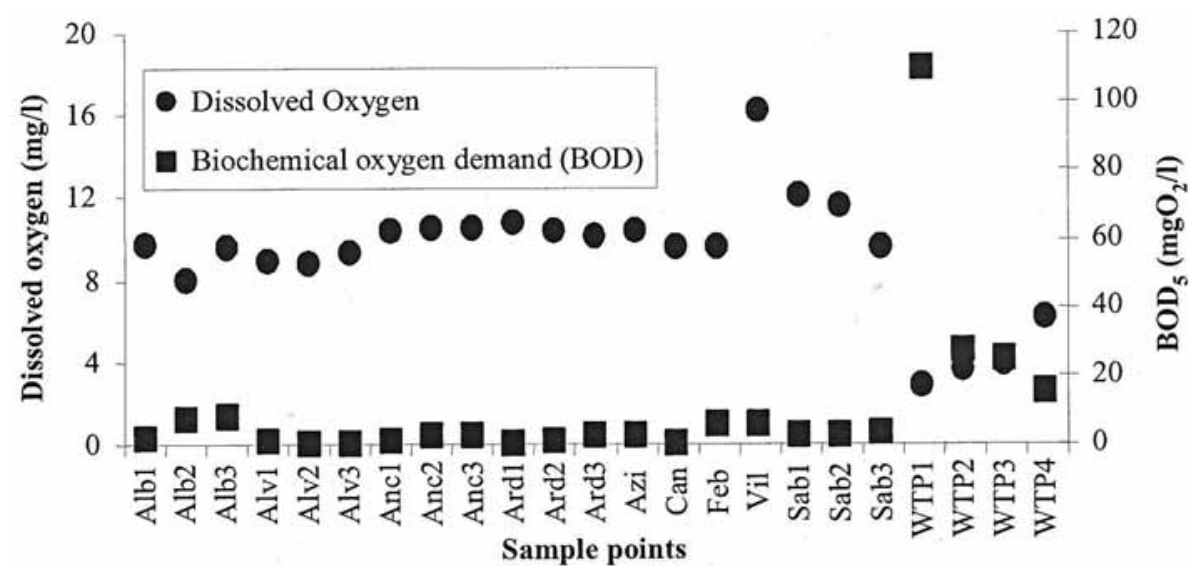

Figure 2. Graphical representation of the spatial variation of the dissolved oxygen concentration in water and the biochemical oxygen demand $\left(\mathrm{BOD}_{5}\right)$ Representación gráfica de la variación espacial de la concentración de oxigeno disuelto en agua y de la demanda bioquímica de oxigeno $\left(\mathrm{DBO}_{5}\right)$.

- Reference points or points with a low degree of perturbation that present the highest diversity, richness, and equitability values: 2 first points in the Ardena (Ard1, Ard2), Alva (Alv1, Alv2), and Âncora rivers (Anc1, Anc2), Azibo river (Azi), Caniça stream (Can), and the upstream point of Sabor river $(\mathrm{Sab} 1)$

- Sampling sites very perturbed with the lowest diversity, richness, and equitability values: lagoons of the wastewater treatment plant

- Sampling sites with a moderate degree of pollution (Table 2)

The upstream sampling point of Sabor river (Sab1) that is included in the first group in spite of the values of the different biotic parameters is located in one place where there isn't any apparent type of pollution source and their bank's state of conservation seems good. These facts and the results obtained by the analysis of physico-chemical parameters allow us to say that it presents a good ecological state for this type of river. The results obtained with the macroinvertebrate communities can be influenced by the sampling methodology or by the lack of accuracy of the analysed parameters for this kind of river.

The spatial ordination of the samples, attending the distribution of organisms on the respi- ratory groups as defined by the n-MDS analysis, defines 3 significantly different (rglobal = 0.896) clusters of samples (Fig. 3a). The first one includes the more polluted or perturbed sampling sites (WTP1, WTP2, WTP3, Alb1, Alb2, Alb3, Feb and Alv3) where there is a dominance of the special cases (figure $3 b$ ). The second group includes the points with a moderate degree of perturbation (WTP4, Sab2, Sab3, Alv2, Ard2, Ard3, Anc2, Anc3), where the organisms with high resistance to pollution are dominant, but where it is possible to observe also the presence of some more sensitive organisms (branchial respiration) (Fig. 3b). Finally, the $3^{\text {rd }}$ cluster includes points that can be classified as reference sites (Sab1, Anc1, Ard1, Alv1, Azi, Can, Vil) with communities dominated by the presence of more sensitive organisms as they exhibit branchial respiration (Fig. 3b).

\section{Case study 2-Wastewater Treatment Plant}

The analysis of the spatial variations of the analysed physico-chemical parameters shows, as it was expected, that there is an increase of water quality along the depuration process (Jesus, 1996) (Fig. 4)

The analysis of the spatial variation of some parameters and indexes related to the macroinvertebrate communities shows results that seem 
a)

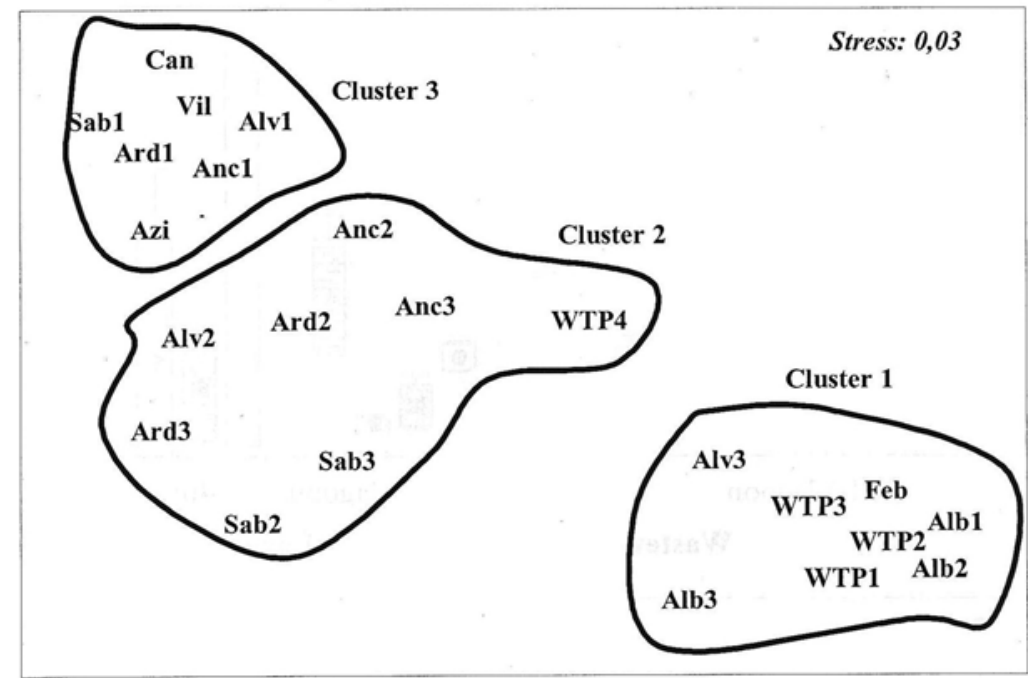

b)

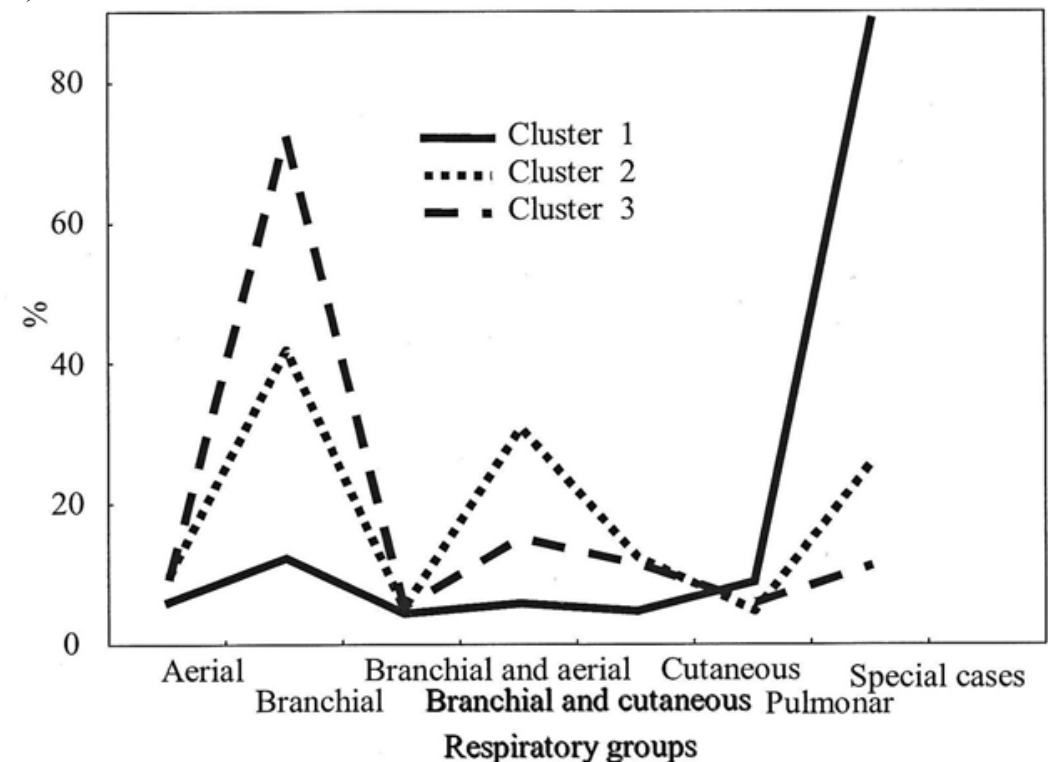

Figure 3. Sample point ordination made with the n-MDS technique with Euclidean distances between samples, using the respiratory groups (a) and average of each respiratory group in each cluster (b). Ordenación de las estaciones de muestreo realizada mediante la técnica n-MDS con la distancia euclidiana entre las muestras, utilizando los datos los grupos respiratorios (a) y media de cada grupo respiratorio en cada cluster $(b)$.

to be contradictory with the obtained by the study of physico-chemical parameters (Fig. 5), showing that the water quality varies between the moderated polluted and extremely polluted and that there is a water quality degradation during the depuration process. This can be explained by the almost exclusive presence of the Chironomidae in the last lagoon (WTP4) and by some problems of the sampling process; facts that affect the calculus of the biotic indexes and the diversity indices (Jesus, 1996).

The spatial ordination of the samples attending to the distribution of organisms in the respiratory groups, as defined by the n-MDS analysis defines 3 


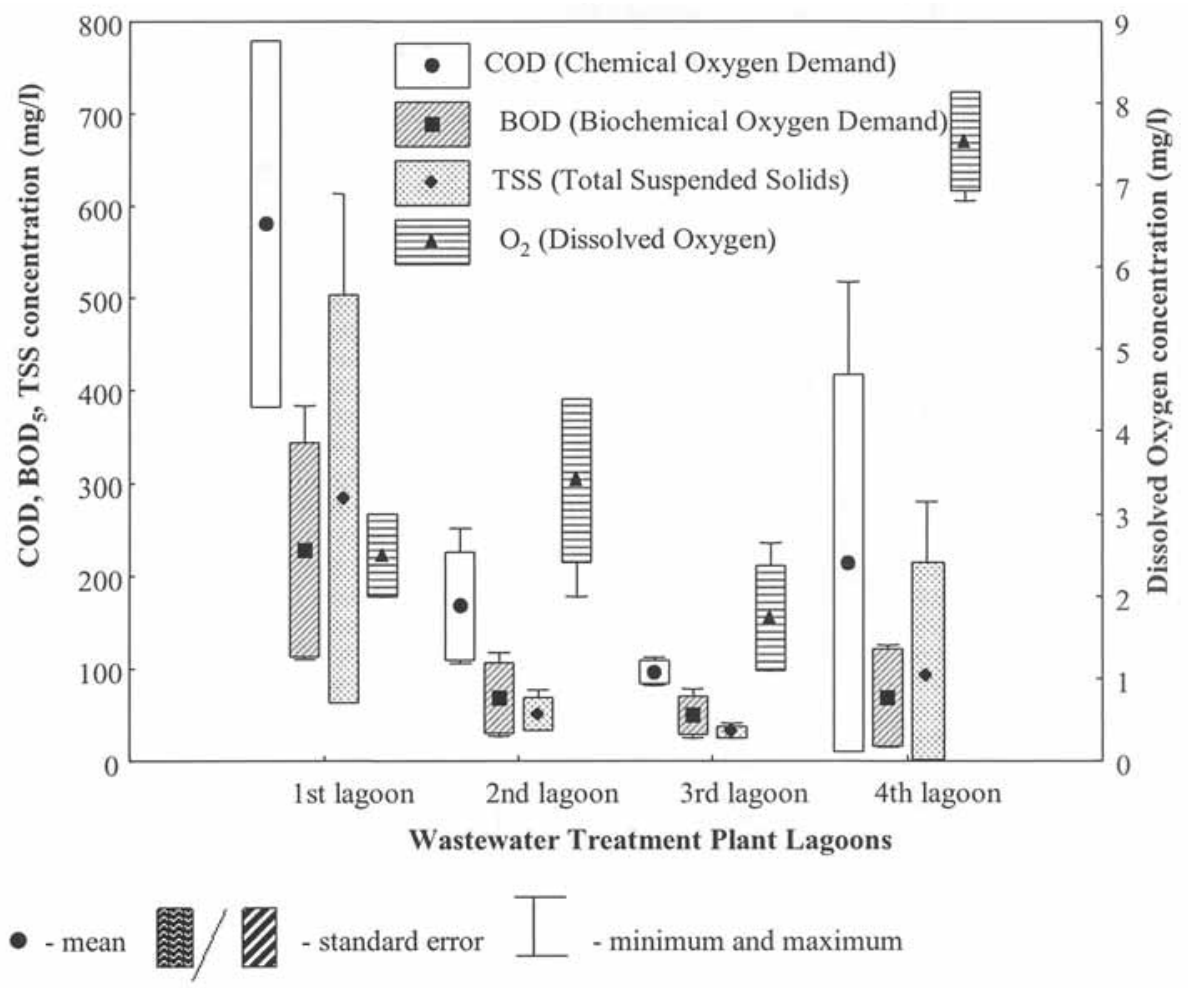

Figure 4. Graphical representation of the spatial variation of the physico-chemical parameters in each lagoon of the wastewater treatment plant. Representación gráfica de la variación espacial de los parámetros físico y químicos en cada laguna de la depuradora.

significantly different (rglobal $=0,896)$ clusters of samples (Fig. 6a). One group includes the samples collected on the maturation lagoon (WTP4) where it is possible to observe the presence of some of the more sensitive organisms (branchial or branchial and cutaneous respiration). The other two groups include samples of the other 3 lagoons (WTP1, WTP2, WTP3) in different seasons and their separation is due mainly to the different distribution of the special cases and the organisms with aerial respiration. (Fig. 6b) These results are very similar to the obtained with the analysis of the physico-chemical parameters.

\section{DISCUSSION AND CONCLUSIONS}

The respiratory groups include organisms with different environmental sensibilities that can be found in every kind of systems.

The presence of macroinvertebrates with bran- chial or cutaneous respiration in an ecosystem can indicate that this ecosystem has good biological water quality and the capacity to support a diversified biotic community (Resh \& Rosenberg, 1984).

The presence of the other respiratory groups (pulmonary, branchial, and air directly) and the absence of organisms with branchial or cutaneous respiration seem to indicate a degradation of the biological water quality (Resh \& Rosenberg, 1984; Ross et al., 1982).

On the sampling sites with the worse water quality, there are almost only organisms with aerial respiration and are included on the special cases.

The results obtained with the respiratory groups are more informative than the ones obtained with the analysis of the physico-chemical parameters because when sampling sites of different rivers are analysed together, the use of respiratory groups allow for the differentiation between points of each river and the grouping of points of different rivers but with similar biolo- 

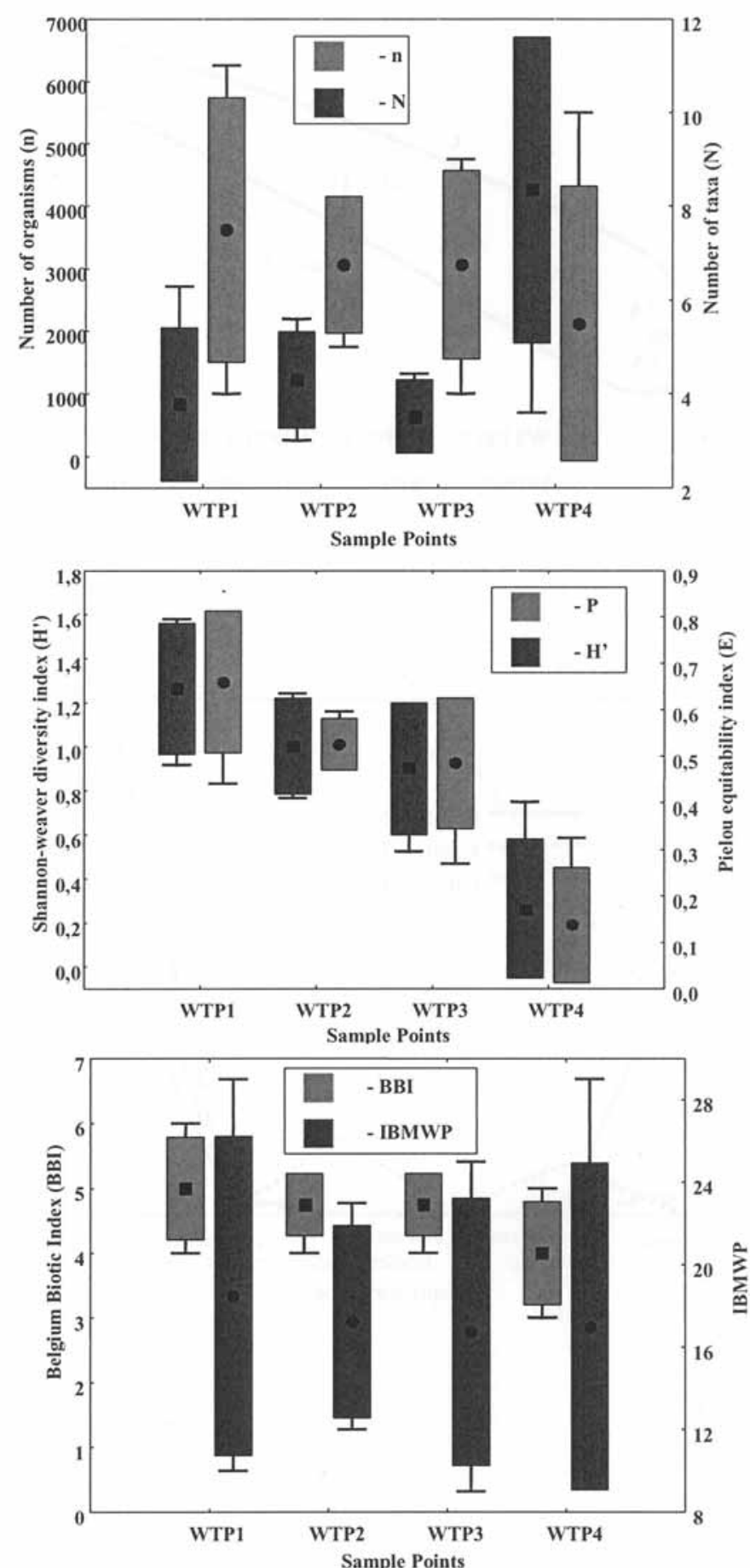

- mean

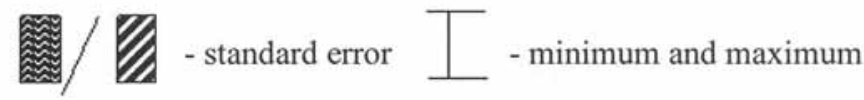

Figure 5. Graphical representation of the spatial variation of some indexes and metrics related with the benthic macroinvertebrate communities. Representación gráfica de la variación espacial de algunos índices y métricas relacionados con las comunidades bentónicas de macroinvertebrados. 


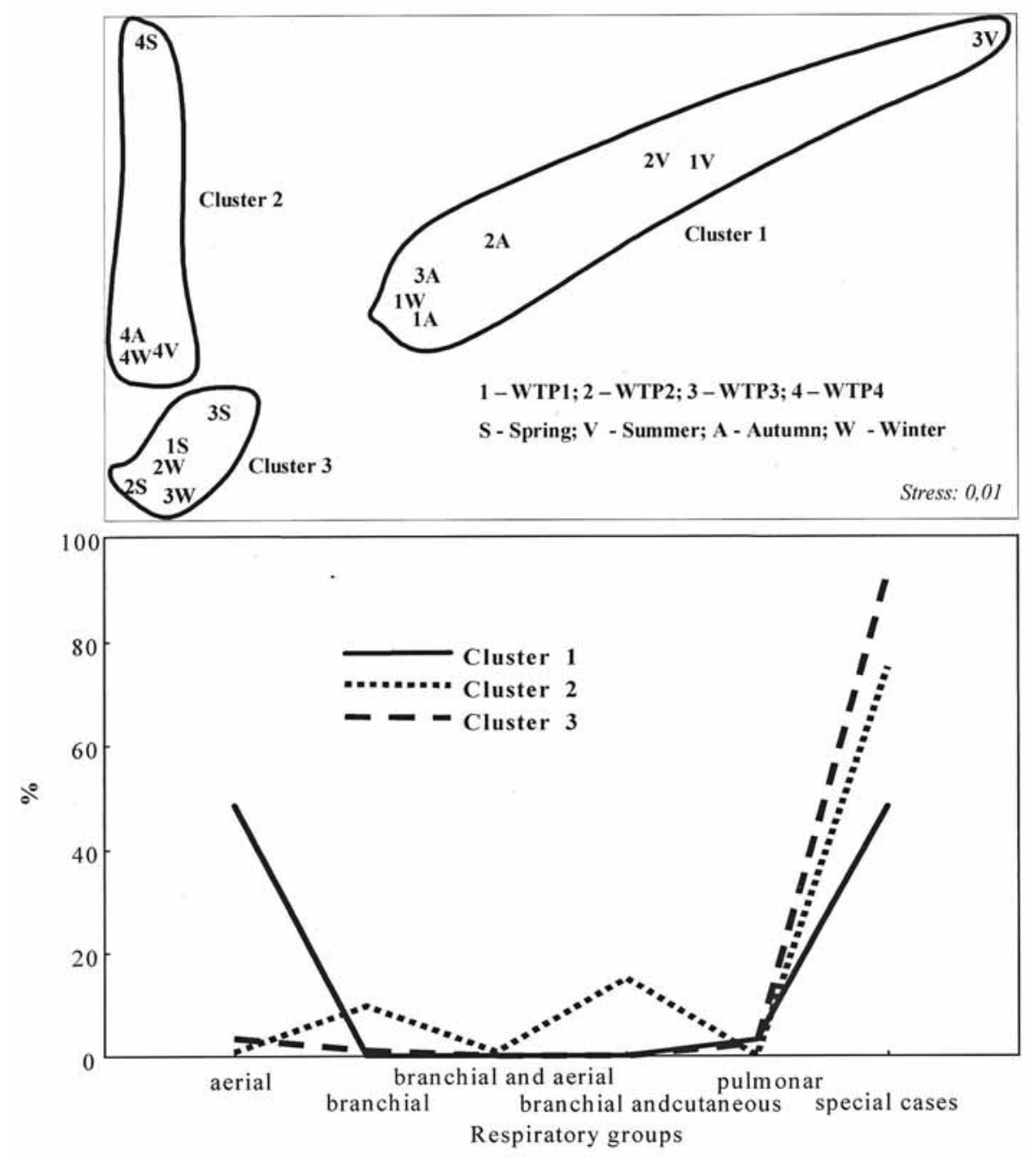

Figure 6. Sample point ordination made with the n-MDS technique with Euclidean distances between the samples, using the respiratory groups (a) and average of each respiratory group in each cluster (b). Ordenación de las estaciones de muestreo realizada mediante la técnica n-MDS con la distancia euclidiana entre las muestras, utilizando los datos los grupos respiratorios (a) y media de cada grupo respiratorio en cada cluster $(b)$.

gical water quality. These results are supported by other ones obtained in other studies (Jesus, 1996, Jesus, 2001, Usseglio-Polatera, 1994).

The comparison of the results obtained with calculations from some biotic parameters and indexes, with those obtained by the use of respiratory groups, shows that in some cases the calculations from biotic indices can lead to false conclusions. In the case of the diversity indices this can be explained by the fact that they do not include aspects about the sensibility of or- ganisms to the contamination levels and because some times they can overestimate one population, particularly if it is a small population. One of the main problems of the biotic indices is their lack of plasticity for their application on every kind of ecosystems and the need to tailor them for the different hydro-regions considered (Washington, 1984).

In this way, the use of aspects related to the structure of the communities and their anatomical, physiological, and behavioural characteristics 
seems to be an important tool for the determination of the biological water quality and for the adaptations that need to be made to the biotic indices.

\section{REFERENCES}

APHA. 1992. Standard Méthods for the examination of water and wastewater. $18^{\mathrm{a}}$ ed., $1268 \mathrm{pp}$.

ALBA-TERCEDOR, J. y A. SANCHÉZ-ORTEGA. 1988. Un método rápido y simple para evaluar la calidad biologica de las águas corrientes basado en el de Hellawell (1978). Limnetica, 4: 51-56

CAMPAIOLI, S., P. GHETTI, A. MINELLI e S. RUFFO. 1994. Manuale per il riconoscimento dei Macroinvertebrati delle acque dolci italiane, Vol.I. Provincia Autonoma di Trento, 357 pp.

CAMPAIOLI S., P. GHETTI, A. MINELli e S. RUFFO. 1999. Manuale per il riconoscimento dei Macroinvertebrati delle acque dolci italiane, Vol.II. Provincia Autonoma Trento, 127 pp.

CHINER, Y. M. 1992. Insectes d'Europe. Multiguide nature. Bordas, $380 \mathrm{pp}$.

CLARCK, E. K. 1993. Non-parametric multivariate analyses of changes in community structure. Aust. J. Ecol., 18: 117-143.

CLARCKE, K. \& R. GREEN. 1988. Statistical design and analysis for a "biologist effects" study. Mar. Ecol. Prog. Ser., 46: 213-226

CLARCKE, K., R. WARWICK \& B. BROWN. 1993. An index showing breakdown of seriation related to disturbance, in a coral-reef assemblage. Nar. Ecol. Prog. Ser., 102: 153-160

CLARCKE, K. \& R. WARWICK. 1994. Change in marine communities: an approach to statistical analysis and interpretation. Plymouth Marine Laboratory, UK. $144 \mathrm{pp}$.

De PAUW, N. \& G. VANHOOREN. 1983. Method for biological quality assessment of watercourses in belgium. Hydrobiol., 100: 153-168

FAESSEL, B. 1985. Les Trichoptères. Données biologiques, éthologiques et écologiques. Clés de détermination larvaire des familles et des principaux genres de France. Bull. Fr. Pêche Piscic., 299: 1-41

FIELD, J., K. CLARCKE \& R. WARWICK. 1982. A practical strategy for analysing multispecies distribution patterns. Mar. Ecol. Prog. Ser., 8: 37-52.

FITTER, R. \& R. MANUEL. 1994. Lakes, rivers, streams \& ponds of Britain \& North-West Europe. Collins photo guide. Harper Collins Publishers, $382 \mathrm{pp}$.
FOREY, P. y P. FOREY. 1995. Vida animal nos rios e nos lagos. Guia prático para identificar as espécies animais que vivem na água doce. Plátano, Edições técnicas, $125 \mathrm{pp}$.

FOREY, P. y C. FITZSIMONS. 1996. Insectos. Guia prático para reconhecer facilmente as variedades de insectos mais comuns da Europa. Plátano, Edições técnicas, $126 \mathrm{pp}$.

GASITH, A. \& V. RESH. 1999. Streams in mediterranean climate regions. Abiotic influences and biotic responses to predictable seasonal events. Annu. Rev. Ecol. Syst., 30: 51-81.

GILLER, K. \& B. MALMQVIST. 1998. The biology of streams and rivers. Oxford University Press, England, $296 \mathrm{pp}$.

HYNES, H. 1979. The ecology of running waters. Liverpool University Press. $555 \mathrm{pp}$.

JESUS, T. 1996. Avaliação da eficiência e do impacto da ETAR de Albergaria-a-Velha através do estudo das comunidades de macroinvertebrados bentónicos. Dissertação de mestrado apresentada à Faculdade de Ciências da Universidade do Porto, $161 \mathrm{pp}$.

JESUS, T. 2001. Centrais hidroeléctricas de pequena dimensão: impacto na dinâmica da comunidade de macroinvertebrados bentónicos e na variação da qualidade da água (Mini-hídrica de Vila Viçosa e "Cascata" do Alva). Dissertação de doutoramento apresentado à Faculdade de Ciências da Universidade do Porto, $235 \mathrm{pp}$.

LAFONT, M. 1983. Annélides Oligochètes. Bull. Men. de la Soc. Lin. de Lyon, 4: 107-135.

MOUTHON, J. 1982. Les Mollusques dulcicoles. Données biologiques et écologiques. Clés de détermination des principaux genres de Bivalves et de Gastéropodes de France. Bull. Fr. Piscic., 5: 127.

MOUTHON, J. 1992. Peuplements malacologistes lacustres en relation avec la physico-chimie de léau et des sédiments II. Les espèces. Annls. Limnol., 28(2): 109-119.

PECKARSKY, B., S. HORN, \& B. STATZNER. 1990. Stonefly predation along a hydraulic gradient: a field test of the harsh-benign hypothesis. Freshwat. Biol., 24: 181-191.

PUIG, M. A. 1999. Els macroinvertebrats dels rius catalans. Guia il-lustrada. Generalitat de Catalunya. Departament de Medi Ambient, 251 pp.

REICHOLF-RHIEM, H. 1995. Insects y Arácnidos. Guías de Naturaleza Blume. 286 pp. 
RESH, V. \& D. ROSENBERG. 1984. The ecology of aquatic insects. Praeger. 625 pp.

ROSS, H., C. ROSS \& J. ROSS. 1982. A textbook of entomology. John Wiley \& Sons. 666 pp.

STATSOFT, INC. 1998. STATISTICA for Windows (Computer Manual). Tulsa, OK. 1098 pp.

STATZNER, B., V. RESH \& A. ROUX. 1994. The synthesis of long-term ecological research in the context of concurrently developed ecological theory: design of a research strategy for the Upper Rhône River and its floodplain. Freswat. Biol., 31: 253-263.

STRICKLAND, J. \& T. PARSONS. 1972. A practical handbook of seawater analysis. Fish. Res. Bd.
Can., 167 (2nd ed.). 311 pp.

USSEGLIO-POLATERA PH. 1994. Theorethical habitat templets, species traits, and species richness: aquatic insects in the Upper Rhône River and its floodplain. Freshwat. Biol., 31: 417-437

WASHINGTON, H. G. 1984. Diversity, biotic and similarity indices. A review with special relevance to aquatic ecosystems. Wat. Res., 18(6): 653-694.

WELCH, P. 1948. Limnological methods. McGrawHill Internat. Ed. $381 \mathrm{pp}$.

WETZEL, R. 1993. Limnologia. Fundação Callouste Gulbenkian. 919 pp.

WILLIAMS, D. D. \& B. W. FELTMATE. 1992. Aquatic insects. C. A. B. International. 358 pp. 